\title{
Optimization of ceramic manufacturing process using Plackett-Burman design of experiment
}

\author{
ÁDÁM EGÉSZ - Department of Ceramics and Silicate Engineering, University of Miskolc, Miskolc, \\ (Hungary) • GE Hungary Ltd., Budapest, (Hungary) · adam.egesz@ge.com \\ SvetLANA P. BUYAKOVA - sbuyakova@ispms.tsc.ru \\ SERGEY N. KULKOV - kulkov@ispms.tsc.ru \\ LÁszLó A GÖMZE - Department of Ceramics and Silicate Engineering, University of Miskolc, Miskolc, \\ (Hungary)· femgomze@uni-miskolc.hu \\ Received: 28. 06. 2014. " Érkezett: 2014. 06. 28. " http://dx.doi.org/10.14382/epitoanyag-jsbcm.2014.11
}

\section{Abstract}

In this research, the authors describe the ceramic injection molding process, and its most important features. Using the method of design of experiment, the connection was discovered between the adjustable machine parameters and the quality of end product, especially highlighted the cracks in the ceramic body. The researchers found as main result, that the machine settings have more impact on the quality of end product, than the applied mold temperatures during injection molding. Furthermore, the holding pressure had the highest impact on the weight of end product, the weight increased with the holding pressure according to a linear relationship.

Keywords: alumina powder, ceramic injection molding, design of experiment, feedstock, paraffin wax
\end{abstract}

Prof. Svetlana P. BUYAKOVA Doctor of Sciences from 2008, full Professor from 2013. She is specialist in material sciences of ceramics and ceramic matrix composites based on oxides and carbides. She is author and co-author of more than 100 papers. Three Ph.D. students and one person makes they dissertations under her guidance in period 2010-2013. Now, she is chief scientist in IS PMS RAS and professor in Tomsk State University and Tomsk Polytechnic University. Her teaching experience: Introduction to Materials Science,

Fundamentals of Materials Engineering, Materials and their Applications.

\section{Introduction}

The sophisticated ceramic, plastic and powder metallurgy industries and technologies require higher and higher demands against quality, volume and yield of end product $[1,2]$. In the illuminant industry, for producing arc tube parts for high intensity discharge lamps the applied method is the ceramic injection molding. For producing ceramic arc tube parts (plugs), two different major components are used for producing injection molding raw material (hereinafter: feedstock): high purity alumina powder as the main component, and an organic paraffin wax as binder material. For producing the injection molding feedstock, the wax binder is melted in a sigma-blade mixer, and the alumina powder is sequentially mixed to the wax after it was melted. The properly mixed material is cooled down to room temperature, and - depending on the injection molding machine - it is granulated or crushed with jaw crusher. The fine tuning of the manufacturing process, the determination and controlling of the influential parameters have an outstanding importance on the production of high quality end product. Nevertheless, before any optimization of the feedstock preparation process, it is needed to know, determine and control the parameters of injection molding process. We can optimize the raw material only using a stabile, robust, properly adjusted injection molding machine, and therefore, the material properties and the producing process will be set for this optimized injection molding process, to decrease the amount of cracked ceramics [3-5]. Namely, in the present case, the output parameter eventually will be the injection molded, sintered parts, and their quality, and if the different materials are tested using a non-optimized injection molding process, then the injection molding will be only noise factor in the material experiments [6].

\subsection{The properties of applied injection molding machine}

The experimental ceramic parts (plugs) (Fig. 1) were made on full electronic injection molding machine with different settings.
Prof. Sergey N. Kulkov Prof. Kulkov is head of Department of Ceramics in the Institute of Strength Physics and Materials Science of the Russian Academy of Science since 1989. He has got scientific degrees „Doctor of Physics and Mathematical Sciences" in 1990. Since 1992 he's working as professor both in Tomsk State University and in Tomsk Polytechnic University. In 1997 he had a Soros Professor grant. His research works are represented in 5 books, more than 150 articles, 18 patents and many International Symposiums and Conferences. At present he is head of department „Theory of Strength and Mechanic of Solids", member of "The American Ceramic Society" of "The APMI International" and the DYM AT Society (France).

Prof. László A. Gömze Establisher (in July 1st, 1999) and head of Department of Ceramics and Sillicate Engineering in the University of Miskolc, Hungary. Since then 7 students from the department have successfully completed their PhD theses and 4 of them were managed by Prof. Gömze. He is author or coauthor of 2 patents, 5 books and more than 250 scientific papers. Recently, he is the chair of

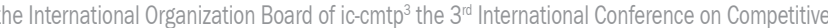
Materials and Technological Processes (2014) and ic-rmm ${ }^{2}$ the $2^{\text {nd }}$ International Conference on Rheology and Modeling of Materials (2015).
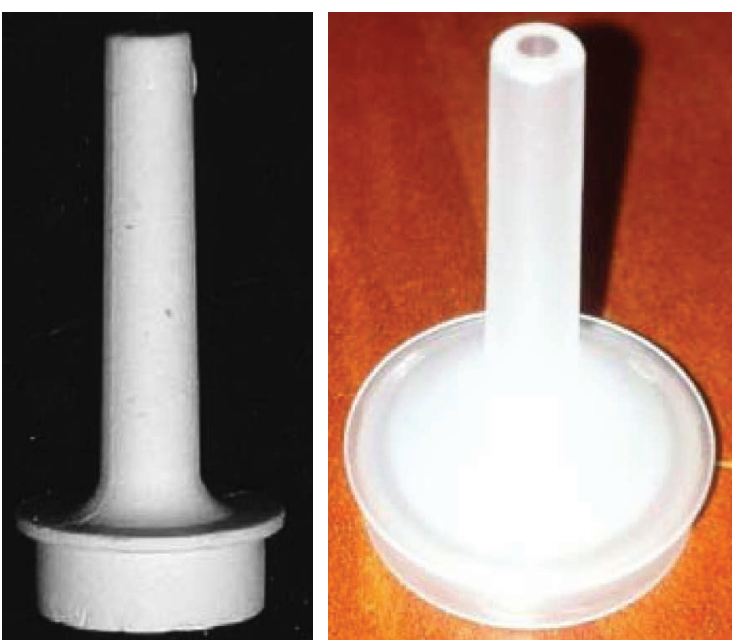

Fig. 1. Injection molded green part (a) and end product (b)

1. ábra Fröccsöntött nyers darab (a) és késztermék (b) 
During molding, five external heating units can provide the proper temperature in the different parts of the mold: 2 heating units heat the hot side of the mold (manifold, tip), 2 units heat the cold side of the mold (side action and plug), and 1 unit heats the metering zone (barrel). Besides that, the machine is equipped with electronic nozzle heat (Fig. 2).

Since the machine is fully electronic, therefore it is well adjustable, and absolutely appropriate and usable for experimental purpose.

The elements and run order of an injection molding cycle can be seen in Fig. 3.

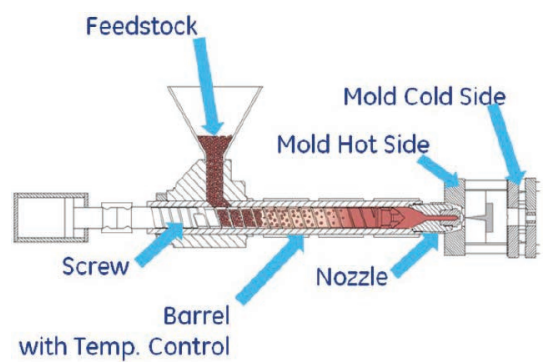

Fig. 2. The structure of injection molding machine

2. ábra A fröccsöntö berendezés szerkezeti felépitése

\subsection{Injection}

During injection the screw linearly moves forward like a piston, and pushes material into the mold. During the process a closing ring under the screw tip ensures the material to flow into the mold, and not move backward in the barrel. During the injection phase $95-99 \%$ of the material of end product is added into the cavities [7-10].

The injection phase ends with reaching the switching point, which switch in the holding pressure section.

\subsection{Holding pressure / Holding time}

The injection phase is followed by the holding pressure phase. During the holding pressure phase the screw slightly moves forward with very low speed, since the mold cavity is almost full of material during the injection molding phase. The holding pressure gives the material, which fully load the mold cavity and complements the material loss from volume reduction due to the cooling of the part [11-14].

During the holding pressure phase, the control of the movement of the screw is provided by pressure values, and not by velocity, like in the injection section.

The holding time is the duration of holding pressure.

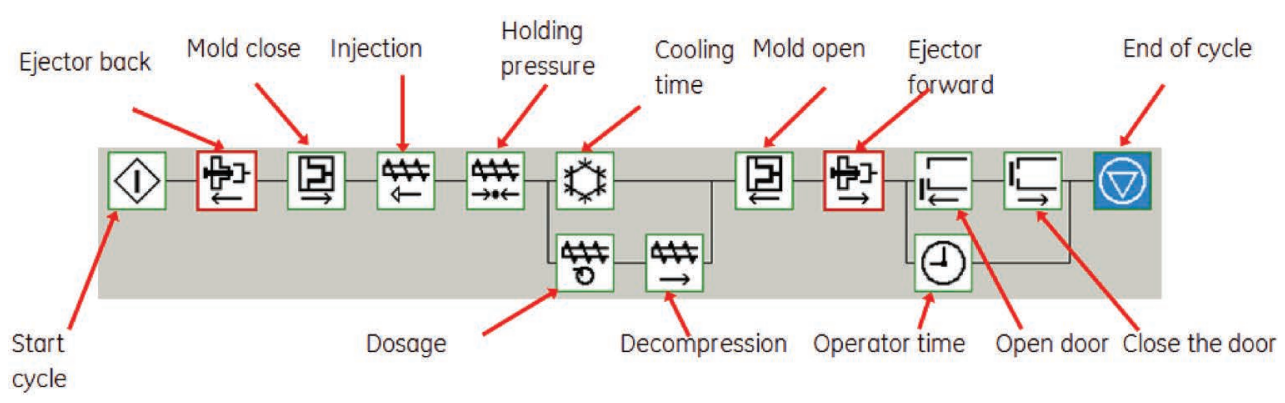

Fig. 3. Cycle diagram of injection molding

3. ábra Egy fröccsöntési ciklus folyamatábrája

\subsection{Dosage}

After the holding pressure phase the screw starts to rotate and carries material forward. In front of the screw, the accumulated material pushes the screw backward. The duration of this phase is the time until the screw reaches the prescribed dosage length (material amount) in front of the screw.

The main parameters of the phase are the back pressure and the peripheral speed of the rotating screw (dosage speed).

The dosage speed should be kept low, since higher speed multiplies the wear rate of the screw. If the dosage speed is higher than necessary, the feedstock can be heated up, what is also harmful on the condition of the machine [15].

\subsection{Back pressure}

In the case of electric machines, the back pressure means the pressure, which holds against the accumulated material, which is in front of the screw, and which tries to push the screw backward during the dosage. If the back pressure is too low, the material in front of the screw can not be tight enough, and can be airy during the injection. If the back pressure is too high, the feedstock can be heated up, or due to the too high pressure, the screw can not load the material in the barrel [16].

\subsection{Decompression}

After the dosage phase the screw shortly and linearly moves backward; this is the decompression phase. The role of this phase is to decrease the pressure in the material after the back pressure. If the pressure is too high after the dosage phase, due to the back pressure, the material flows out from the hot side of the mold after the opening of the mold. The duration of this phase is the decompression path lenght [17].

\section{Experimental}

\subsection{Plackett-Burman screening design with 10 factors (DoE)}

The name „Screening Design” refers to a design of experiment, which can select some significant factors from a higher amount of factors, considered potentially adjustable factors.

Alternatively, if the main goal of a design is the identification of the main effects, regardless to the different interactions (which has probably lower magnitude), this design is called also Screening Design.

If one has initially numerous factors, firstly it is expedient to perform a sreening design, even if the final goal is the finding of a total output surface [18].

Typically, the screening design is a 3 level resolution design. This is very important, because the 3 level design can very effectively identify the main effects alias free, with low number of experiments.

\subsection{The aim and implementation of experiment}

As aim of experiment, it was intended to show the most important adjustable parameters of the injection molding machine, which have the highest effect on the yield and the occurrence of cracked parts. 
In the experiment, 10 different factors were investigated on 2 levels, with 15 runs. This means III. level resolution, i.e. the main effects are mixed with second level interactions [19]. There were 3 repeated cells as a part of the design to check the linearity and repeatability.

Every cell consisted of 333 parts. The performance of injection molding was continuous, with the same operator, raw material and molding tool. After the injection molding, the sintered parts were examined.

The investigated outputs (answers) of the experiment were the following:

- the amount (ratio) of cracked parts, yield [\%]

- the weight of green parts [g]

In this research, the Minitab software helped to prepare the design of experiment and its evaluation process.

Based on the engineering point of view, earlier experience and literature [20] research the initially tested factors are shown in Table 1.

\begin{tabular}{lccccc} 
& Factor & Unit & Factor & Unit \\
$\mathbf{1}$ & Injections speed & $\mathrm{mm} / \mathrm{s}$ & $\mathbf{6}$ & Dosage speed & $\mathrm{m} / \mathrm{min}$ \\
\hline $\mathbf{2}$ & Holding pressure & bar & $\mathbf{7}$ & Nozzle temperature & ${ }^{\circ} \mathrm{C}$ \\
\hline $\mathbf{3}$ & Holdinh time & $\mathrm{s}$ & $\mathbf{8}$ & Barrel temperature & ${ }^{\circ} \mathrm{C}$ \\
\hline $\mathbf{4}$ & Switching point & $\mathrm{mm}$ & $\mathbf{9}$ & Mold cold side temperature & ${ }^{\circ} \mathrm{C}$ \\
\hline $\mathbf{5}$ & Back pressure & bar & $\mathbf{1 0}$ & Mold hot side temperature & ${ }^{\circ} \mathrm{C}$
\end{tabular}

Table 1. Tested factors

1. táblázat A vizsgált faktorok

In Minitab software, in the yield-related analysis is better to use the transformed yield [21] instead of the good/all parts ratio, which is shown in eq. (1):

Yield $_{\text {Transz }}=\frac{100}{90} \cdot \operatorname{ASIN}\left(\sqrt{\frac{\text { Good parts }}{\text { All parts }}}\right)$

The transformed yield can approach the normal distribution, thus the results can be analysed more effective using the usual Minitab evaluation tools [22].

\section{Results and discussion}

Investigating the transformed yield of the parts, the following statements can be taken:

It can be observed on the Pareto chart of main effects (Fig. 4), that all main factors have significant effect on the transformed yield, except the nozzle temperature. The Pareto chart also gives an order by the level of the different effects. The most important 4 factors are the back pressure, holding pressure, injection speed and holding time.

The main effect plot (Fig. 5) shows, that which directions of factors have effect on the increasing of good end parts [23]. Based on Fig. 5, the low level of injection speed, the high level of the holding pressure, holding time and back pressure are favorable in the low crack amount point of view.

On the main effect plot (Fig. 5), the average yields of center points are indicated by the blue dots. Based on the data of center points, one can determine a strong non-linearity. By evaluation of results, it is important to highlight, that the perspicacity was made more difficult by the non-linearity and the low resolution of the experiment, due to the mixing of main and secondary interactions [24].

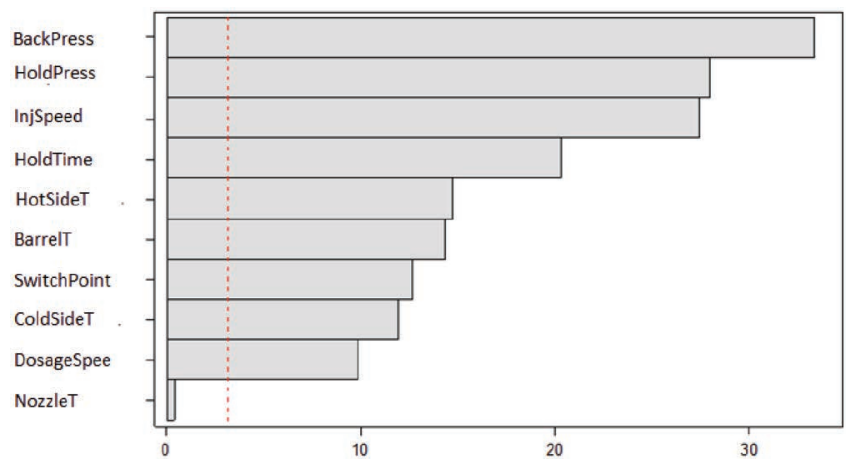

Fig. 4. Pareto chart of main effects

4. ábra A föhatások Pareto-ábrája

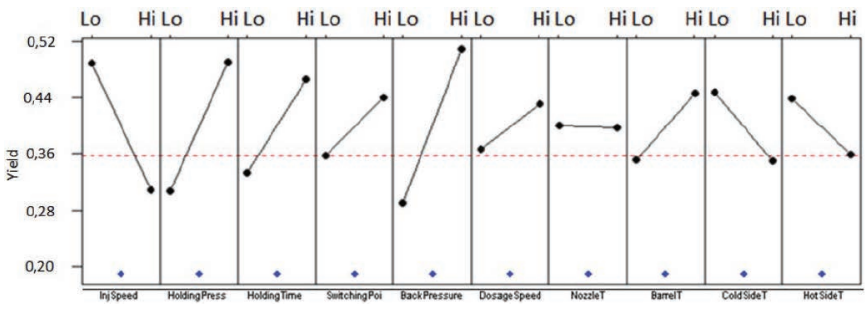

Fig. 5. Main effect plot

5. ábra Főhatás ábra

Summary of the experimentally found settings for the different machine factors can be seen in Table 2 .

\begin{tabular}{lc} 
& Screeninbest \\
\hline Back pressure & High \\
\hline Holding pressure & High \\
\hline Injection speed & Low \\
\hline Holding tome & High \\
\hline Switching point & Medium \\
\hline Dosage speed & High \\
\hline Cold side temp. & Low \\
\hline Hot side temp. & Medium \\
\hline Barrel temp. & High \\
\hline Nozzle temp. & Medium
\end{tabular}

Table 2. Experimental settings, the optimal level of factors

2. táblázat A kísérleti beállítások és a faktorok optimális szintjei

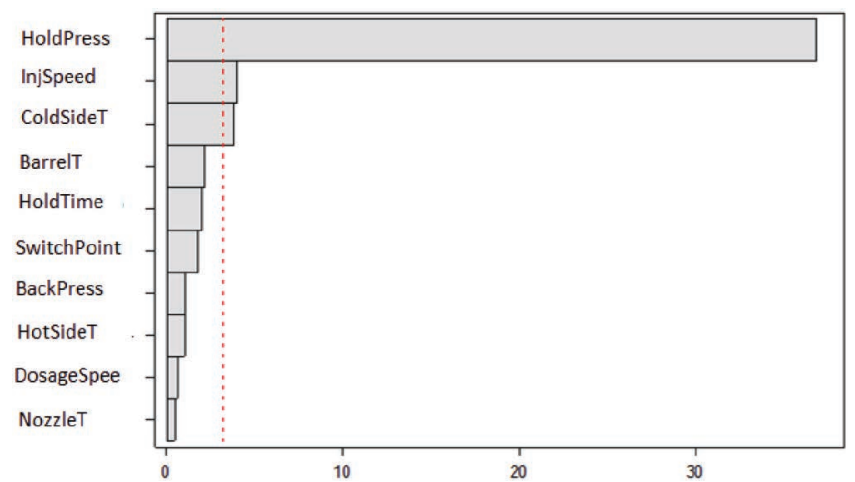

Fig. 6. Pareto chart of main effects for green part weight 6. ábra A nyers termék tömegére vonatkozó Pareto-ábra 


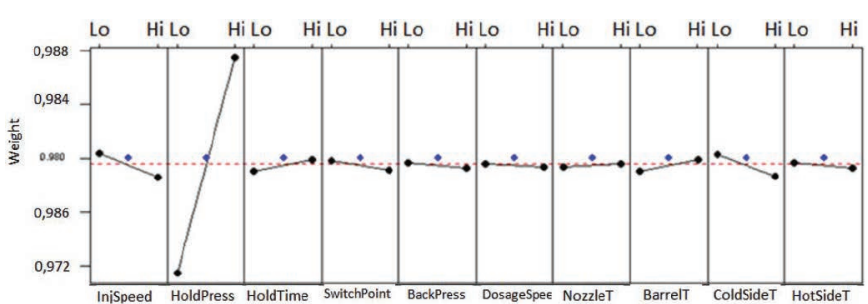

Fig. 7. Main effect plot of factors for the green part weight

7. ábra A nyers termék tömegére vonatkozó föhatás-ábra

Observing the average weight related Pareto chart (Fig. 6) one can establish, that the value of holding pressure is the most significant factor for this output. On the main effect plot it can be seen, (Fig. 7) that higher holding pressure resulted higher green product weight, and the connection between these two parameters is approximately linear in the investigated range.

\section{Conclusions}

According to the results of literature research, the prepared experiments and the present observations, the folloving considerations can be taken:

The method of design of experiment is especially suitable for optimizing a given injection molding process, and the optimal setting for a given end product can be found. It was seen, that using the multi-factor Plackett-Burman Screening design, the less important factors could be safely filtered, and the optimal settings could be found.

According to the experiments it was established, that the machine settings have more impact on the quality of end product than the applied mold temperatures during injection molding.

The holding pressure had the highest impact on the weight of end product, the weight increased with the holding pressure according to a linear relationship.

\section{References}

[1] Emri, I. - Prodan, T.: Measuring system for bulk characterization of polymers. Experimental Mechanics, Vol. 46, No. 4., pp.429-439, 2006 http://dx.doi.org/10.1007/s11340-006-8528-4

[2] Florjancic, U. - Zupancic, B. - Emri, I.: The effect of processing conditions on the durability of polymer products. Int. J. Microstructure and Materials Proporties, Vol. 4., pp. 576-593, 2009 http://dx.doi.org/10.1504/IJMMP.2009.031592

[3] Piotter, V. - Gietzelt, T. - Merz, L.: Micro powder-injection moulding of metals andceramics. Sadhana, Vol. 28, Parts 1 \& 2, 2003 http://www.ias.ac.in/sadhana/Pdf2003Apr/Pe1066.pdf

[4] Piotter, V. - Plewa, K. - Prokop, J. - Ruh, A.: Manufacturing of Versatile Ceramic or Metal Micro Components by PowderInjection Moulding. Proc. of the 4th Internat.Conf. on Multi-Material MicroManufacture, Cardiff, 2008

[5] Piotter, V. - Mueller, T. - Plewa, K. - Prokop, J.: Manufacturing of complex-shaped ceramic components by micropowder injectionmolding. The International Journal of Advanced Manufacturing Technology, 2010 http://dx.doi.org/10.1007/s00170-009-2095-7

[6] Rak, Z. S.: New trends in powder injection moulding. Powder Metallurgy and MetalCeramics, Volume 38, Numbers 3-4, 1999 http://dx.doi.org/10.1007/BF02676037

[7] Wei, W. C. J. - Wu, R. Y. - Ho, S. J.: Effects of pressure parameters on alumina made bypowder injection moulding. Journal of the European Ceramic Society, Volume 20, Issue9, 2000 http://dx.doi.org/10.1016/S0955-2219(99)00295-2
[8] Zlatkov, B. S. - Mitrovic, N. S. - Nikolic, M. V.: Properties of MnZn ferrites prepared by powder injectionmolding technology. Materials Science and Engineering,2010

http://dx.doi.org/10.1016/j.mseb.2010.07.031

[9] Mutsuddy, B. C.: Equipment selection for injection moulding, Ceram. Bull. 68,10, 1989

[10] Emri, I.: The role of pressure in the behavior of time-dependent Materials. in Recent Advances in Experimental Mechanics, Edited by E.E. Gdoutos, pp. 19-30, Kluwer Academic Publisher, the Netherlands, 2002

[11] German, R. M.: Global research and development in powder injection moulding, Powder Injection Moulding International 1, 2007

[12] German, R. M.: Divergences in global powder injection moulding; Powder InjectionMoulding International 2, 2008

[13] Maetzig, M.: Strategies for injection moulding metals and ceramics.In: Proceedings of the 2002 World congress on Powder Metallurgy \& Particulate Materials, Orlando, Florida, 2002

[14] Lenk, R.: Hot Moulding 2 An Interesting Forming Process, cfi, Ber. Dtsch. Keram. Ges.,72, 10, 1995

http://publica.fraunhofer.de/dokumente/PX-17497.html

[15] Verpoort, P. J.: Overview of powder injection moulding, Advanced performancematerials, 3, 2, 1996

[16] Ballard, C.: Ceramic injection moulding meets the demand for manufacturing complexshapes, Ceramic Industry 147, 1997

[17] Wroblewska, G. H.: Structural ceramics with complex shape - forming methods, Ceramic Engineering and Science Proceedings, 22, 2001 http://dx.doi.org/10.1002/9780470294680.ch5

[18] Barker, Thomas B.: Quality by Experimental Design, Marcel Dekker Inc., 1985

[19] Cornell, John A.: Experiments with mixtures, 2nd Edition, John Wiley and Sons, Inc., New York, 1990

[20] Kemény, S. - Deák, A.: Mérések tervezése és eredményeik kiértékelése, Müszaki Könyvkiadó, Budapest, 1990

[21] Bandemer, H.: Some Applications of Fuzzy Set Theory in Data Analysis II, D197, VEB Deutsche Verlag für Grundstoffindustrie, Leipzig, 1990

[22] Rosato, D. V.: Specialized injection molding process. In Injection Molding Handbook, 2nd edition. Chapman \& Hall GmbH, Weinheim, Germany, 1996

[23] Mogyoródi, J. - Michaletzky, Gy.: Matematikai statisztika, ELTE Természettudományi Kar, Nemzeti Tankönyvkiadó, Budapest, 1995

[24] Reimann, J.: Valószínűségszámítás és matematikai statisztika mérnököknek, Tankönyvkiadó, Budapest, 1992

$\underline{\text { Ref.: }}$

Egész, Ádám - Buyakova, Svetlana P. - Kulkov, Sergey N.- Gömze, László A.: Optimization of ceramic manufacturing process using Plackett-Burman design of experiment

Építőanyag - Journal of Silicate Based and Composite Materials, Vol. 66, No. 2 (2014), 52-55. p. http://dx.doi.org/10.14382/epitoanyag-jsbcm.2014.11

Kerámia gyártási folyamat optimalizálása a PackettBurman kisérlettervezési módszer alkalmazásával Jelen kutatásban a szerzôk leírják a kerámia fröccsöntés folyamatát, annak legfontosabb jellemzôit. A kísérlettervezés módszerével bemutatják, hogy miként függ az egyes változtatható gépparaméterektôl a végtermék minôsége, különös tekintettel a kerámiában előforduló repedések megjelenésére. Legfốbb megállapításként elmondható, hogy a fröccsöntéskor beállítható gépparamétereknek sokkal nagyob hatásuk van a végtermék minőségére, mint a fröccsöntés hômérsékletének. Ezen kívül elmondható, hogy a fröccsöntéskor a zöld termék tömegére az utónyomás nagysága van a legnagyob hatással.

Kulcsszavak: alumínium-oxid por, paraffin wax, kerámia fröccsöntés, kísérlettervezés, feedstock 